\title{
EFFECTS OF NUTRITION AND HYGIENE IN PATIENTS SUFFERING FROM ACUTE VIRAL FEVER WITHOUT/WITH LOW PLATELET COUNT
}

\author{
Bora Prasada Rao ${ }^{1}$
}

${ }^{1}$ Associate Professor, Department of Physiology, Rajiv Gandhi Institute of Medical Sciences (RIMS), Srikakulam, Andhra Pradesh, India. ABSTRACT

\section{BACKGROUND}

Nutrition and Sanitation are essential for good health and public well-being. With changing demographics, urbanisation and rural dynamics, a renewed thrust is being given to ensure balanced nutrition and good hygienic conditions. This study tries to explore the link between nutrition and hygienic conditions to acute viral fever with low platelet count (thrombocytopenia). Srikakulam district has been chosen for the study because of its backwardness in the residuary state of Andhra Pradesh. The present study is conducted in Rajiv Gandhi Institute of Medical Sciences (RIMS), Srikakulam; Community Health Centre, Narasannapeta; KIMS Hospital, Srikakulam and GEMS Hospital, Srikakulam.

Aim- To compare the nutritional status of children's fever with and without thrombocytopenia.

\section{MATERIALS AND METHODS}

The descriptive study was conducted in male and female subjects categorised under ill-nourished, moderately-nourished and wellnourished people and across the age groups of 7 - 14, 15 - 24, 25 - 35 and 36 - 60 years over a period of one year. Subjects with severe medical problems like cardiorespiratory, renal, hepatic and gastrointestinal illness were excluded from the study. In this study total 600 patients were taken; among them 350 subjects were suffering from viral fever and 250 patients were affected by viral fever with thrombocytopenia. Case sheets for tracing out the clinical symptoms, signs, vital data like blood pressure (BP), pulse rate, respiratory rate and temperature were designed.

\section{RESULTS}

It was observed that more patients suffering from viral fever with low platelet count were observed in the ill-nourished group (82.4\%) compared to moderately nourished group (14\%). Secondly, in the age-wise categorical study, it was found out that the phenomena of thrombocytopenia is more evident across the young subjects, particularly in the age group of 7 - 14 years (44\%) and 15 - 25 years (24\%). Patients with poor nutrition took long time to recover from fever and thrombocytopenia.

\section{CONCLUSION}

It is clearly evident that many patients with poor nutrition and sanitation were affected. They suffered from fever and that is prolonged and not controlled within 3 - 4 days and platelet counts do not reach normal levels within 11 - 15 days. Proper sanitation and balanced nutrition is necessary for ensuring public health and well-being. Government must ensure proper distribution of rations that includes all parts of a balanced diet. It must also emphasise more on public health education and generating awareness.

\section{KEY WORDS}

Haematological Analysis, Automatic Platelet Analyser, Thrombocytopenia, Nutrition, Complete Blood Count.

HOW TO CITE THIS ARTICLE: Effects of Nutrition and Hygiene in Patients Suffering from Acute Viral Fever without/with Low Platelet Count. J. Evolution Med. Dent. Sci. 2018;7(42):4493-4496, DOI: 10.14260/jemds/2018/1002

\section{BACKGROUND}

Platelets are non-nucleated round or oval biconvex discs, having various sizes and covered by unit membrane. The average size is 2.5 microns. These can be seen in electron microscope clearly. The average lifespan of platelets is about 5 - 9 days. They are destroyed in the spleen and other reticuloendothelial cells. The average number of platelets present per cubic $\mathrm{mm}$ of blood is about 1.5 lakhs - 4.5 lakhs $/ \mathrm{mm}^{3}$. Fairly rapid change in number take place from day-to-day and even from one part of the day to another. Roughly speaking, those physiological conditions which alter the total count of leucocytes also alter the platelet count in the same direction.

'Financial or Other Competing Interest': None.

Submission 07-08-2018, Peer Review 28-09-2018,

Acceptance 04-10-2018, Published 15-10-2018.

Corresponding Author:

Dr. Bora Prasada Rao,

Flat \#501, Katta's Surya Heights,

LBS Colony, Srikakulam-532001, Andhra Pradesh, India.

E-mail: prasadaraobora@gmail.com

DOI: $10.14260 /$ jemds/2018/1002

\section{Development of Platelets}

Megakaryocytes of the bone marrow introduce pseudopodia through the walls of the sinusoids. These processes are broken off in such a way that the individual fragment is surrounded by a unit membrane and are washed away by the blood stream. These fragments with unit membrane are platelets. Functions of platelets include initiating blood clotting, repairing capillary endothelium, haemostatic mechanism and hasten clot retraction. $1,2,3,4,5$

When platelets disintegrate, 5-Hydroxytryptamine and histamine are liberated. 5-Hydroxytryptamine has vasoconstrictor effect and helps in haemostatic mechanism. So low platelet count, i.e. thrombocytopenia is a medical condition ranging from mild-to-severe. It is characterised by haemorrhage beneath the skin and muscular membrane. In physiology, platelets are responsible for blood clotting, thus play a role in preventing excessive bleeding and fluid loss. Low platelet counts can be seen in leukaemia, certain types of anaemia, drugs, alcohol consumption and viral infectious diseases like dengue virus and hepatitis-C. Platelets may be destroyed by bacteraemia and haemolytic uraemic syndrome. 


\section{Objective}

To compare the nutritional status of children's fever with and without thrombocytopenia.

\section{MATERIALS AND METHODS}

The descriptive study of obtaining the approval from RIMS Hospital, CHC Narasannapeta, KIMS Hospital and GEMS Hospital, In this study, a total of 600 patients were taken where 350 subjects were suffering from viral fever and the 250 patients affected by Viral fever with Thrombocytopenia were taken and the study was done on them. Subjects were categorised under different age groups namely 7 - 14 years, 15 - 24 years, 25 - 35 years and 36 - 60 years. The subjects are from diverse backgrounds in terms of region, religion, age, occupation, economic status and habits. In this study, daily complete blood counts were taken. To count the platelet number, different methods were used namely Haemocytometry (direct method); study of blood smears (indirect method) and use of an automatic counting machine.6,7,8 A case sheet for tracing out the clinical symptoms, signs and physical findings was designed. Examined findings were recorded into the designated case sheets. After taking complete history, general physical examination and systemic examination vital data like body weight, blood pressure, pulse rate, respiratory rate and body temperature were recorded. Clinical evaluation of nutritional status was done by the patient's Body Mass Index (BMI) and head to foot examination for specific vitamin and mineral deficiencies. The obtained nutritional status of the subjects was categorised under illnourished, moderately nourished and well nourished.

\section{Statistical Analysis}

Data analysis was done by using Chi-square tests with the help of SPSS. The $p<0.05$ was considered statistically significant.

\section{RESULTS}

Among the 350 subjects considered in the study $68 \%$ were illnourished, $22 \%$ were moderately nourished and remaining $10 \%$ were well nourished as shown in Figure 1 . All the 350 subjects were affected by viral fever. Among them those that also exhibited low platelet count, i.e. thrombocytopenia is depicted in the Figure 2 and Table 1. It is observed that thrombocytopenia is widely present in the ill-nourished category, i.e. $82.4 \%$ (206 out of 250 subjects). When enquired about their hygiene and sanitation practices, it was observed that their sanitation was poor and less care was taken to protect their body hygiene. Secondly, in the age-wise categorical study it was found out that the thrombocytopenia was more evident across the young subjects, particularly in the age group of 7 - 14 years (44\%) and 15 - 25 years (24\%). The detailed break-up is shown in Table 2 . In terms of recovery periods, subjects with poor nutrition took long time to recover from fever and to achieve normal platelet count when compared to others as shown in Tables 3 and 4.

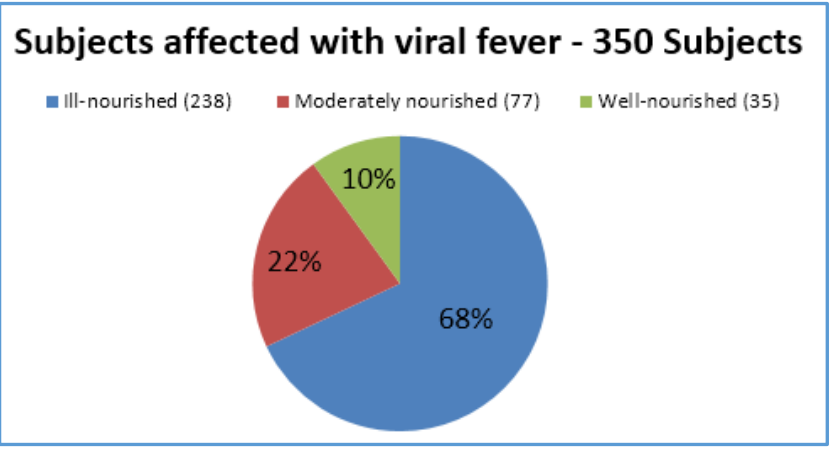

Figure 1. Distribution of Subjects according to their Nutritional Status

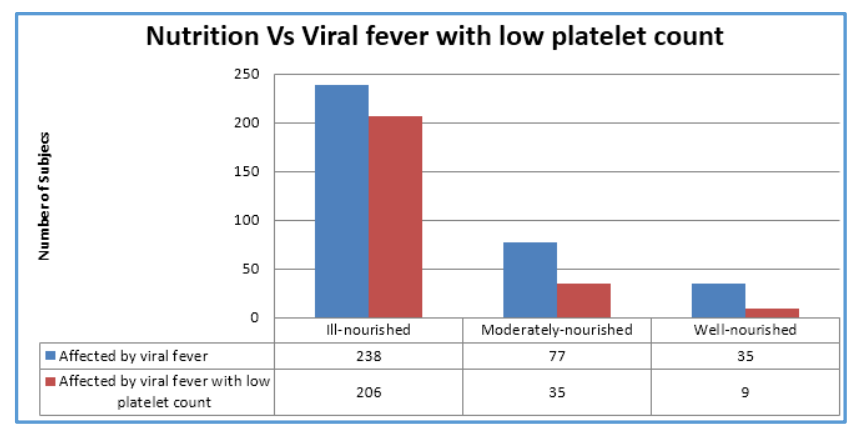

Figure 2. Comparing Subjects affected by Viral Fever and those affected by Viral Fever along with Thrombocytopenia

\begin{tabular}{|c|c|c|c|}
\hline $\begin{array}{c}\text { Nutritional } \\
\text { Status }\end{array}$ & $\begin{array}{c}\text { Subjects } \\
\text { affected by } \\
\text { Viral Fever } \\
\text { (VF) }\end{array}$ & \begin{tabular}{|c|} 
Affected by Viral \\
Fever with \\
Thrombocytopenia \\
(T)
\end{tabular} & $\begin{array}{c}\%(\mathrm{~T} / 250 \\
100)\end{array}$ \\
\hline Ill-nourished & 238 & 206 & $82.4 \%$ \\
\hline $\begin{array}{c}\text { Moderately- } \\
\text { nourished }\end{array}$ & 77 & 35 & $14 \%$ \\
\hline $\begin{array}{c}\text { Well- } \\
\text { nourished }\end{array}$ & 35 & 9 & $3.6 \%$ \\
\hline & Total $=350$ & Total $=250$ & $\begin{array}{l}\text { Total= } \\
100 \%\end{array}$ \\
\hline
\end{tabular}

\begin{tabular}{|c|c|c|c|}
\hline $\begin{array}{c}\text { Age } \\
\text { Groups }\end{array}$ & $\begin{array}{c}\text { Subjects } \\
\text { affected by Viral } \\
\text { Fever } \\
\text { (VF) }\end{array}$ & \begin{tabular}{|c|} 
Affected by Viral \\
Fever \\
Thrombocytopenia \\
(T)
\end{tabular} & $\begin{array}{c}\% \\
([\mathrm{~T} \div 250] \\
* 100)\end{array}$ \\
\hline 7-14 years & 155 & 110 & $44 \%$ \\
\hline $\begin{array}{l}15-24 \\
\text { years }\end{array}$ & 90 & 60 & $24 \%$ \\
\hline $\begin{array}{l}25-35 \\
\text { years }\end{array}$ & 65 & 45 & $18 \%$ \\
\hline \multirow[t]{2}{*}{$\begin{array}{l}36-60 \\
\text { years }\end{array}$} & 40 & 35 & $14 \%$ \\
\hline & Total $=\mathbf{3 5 0}$ & Total $=250$ & $\begin{array}{l}\text { Total= } \\
100 \%\end{array}$ \\
\hline
\end{tabular}

\section{Ill-Nourished Group}

They could not achieve normal platelet count, i.e. 1.5 - 4.5 lakhs/cubic mm till 11 - 15 days. On examination, they were found with fever, rash, body pains, haemorrhagic, hepatitis etc. 


\section{Moderately Nourished Group}

Fever with platelet count was recorded. They recovered in 6-7 days. On examination, no other complications were found.

\section{Daily CBC Report is as follows}

\begin{tabular}{|c|c|c|c|c|}
\hline $\begin{array}{l}\text { Nutritional } \\
\text { Status }\end{array}$ & $\begin{array}{c}\text { Subjects } \\
\text { affected } \\
\text { by Viral } \\
\text { Fever (VF) }\end{array}$ & \begin{tabular}{|c|}
$\begin{array}{c}\text { Affected by Viral } \\
\text { Fever with } \\
\text { Thrombocytopenia } \\
\text { (T) }\end{array}$ \\
\end{tabular} & $\begin{array}{l}\text { Mean } \\
\text { and } \\
\text { SD }\end{array}$ & P value \\
\hline $\begin{array}{c}\text { Ill- } \\
\text { nourished }\end{array}$ & 238 & 206 & 65.320 & $<0.632$ \\
\hline $\begin{array}{c}\text { Moderately- } \\
\text { nourished }\end{array}$ & 77 & 35 & 35.42 & $<0.325$ \\
\hline $\begin{array}{c}\text { Well- } \\
\text { nourished }\end{array}$ & 35 & 9 & 10.65 & $<0.05$ \\
\hline & $\begin{array}{c}\text { Total= } \\
350\end{array}$ & Total $=\mathbf{2 5 0}$ & & \\
\hline
\end{tabular}

Age group 7 - 15 years recovered within 11 - 15 days. In the age group of 36 - 60 years, a few were affected but recovered soon within 1 - 2 days.

Recovery periods: From the daily Complete Blood Counts (CBC), it was observed that the ill-nourished group took 11 to 15 days to achieve the normal platelet count. The moderately nourished group, on the other hand took 6 to 7 days for achieving the normal platelet count.

\section{DISCUSSION}

Platelets participate in the coagulation of blood and therefore associated with the haemostatic mechanisms of the body. Platelet count is usually ordered as a part of the laboratory diagnosis of a bleeding disorder. When the platelet count is increased in the blood, the condition is known as thrombocytosis and the decreased count is called thrombocytopenia. Thrombocytopenia can be caused by impaired production or increased destruction of platelets. Prolonged bleeding time is the hallmark of thrombocytopenia. When the platelet count is less than 50,000/cubic mm of blood, the count is called critical count, as bleeding may occur spontaneously. The haemorrhagic tendency is proportional to the degree of thrombocytopenia and is characterised by petechial, ecchymosis, menorrhagia and bleeding from mucous membranes into the CNS. To differentiate the causes of thrombocytopenia, the bone marrow should be carefully examined. If megakaryocytes are absent in the bone marrow, this implies failure of platelet production.

Nutrition plays a key role in public health and well-being It leads to enhanced immunity levels and protection. But due to improper dietary practices, poor sanitation, the immunity gets weakened and increases susceptibility to viral fever. The above study has established a link between thrombocytopenia and nutrition. It was found that ill-nourished were the most affected with viral fever coupled with thrombocytopenia. Secondly, the age group that remains most affected is between 7 - 25 years that includes children and adults. With growing urbanisation and changing rural dynamics, we are witnessing a massive increase in pollution, growing piles of garbage and wastes and improper sewerage systems. These lead to poor sanitation and unhygienic conditions. Also, the growing incidence of fast-foods, high sugar and fatty foods coupled with inadequate public health education is leading to improper and unbalanced dietary practices. ${ }^{9}$ These are more significantly seen across the young population, primarily due to lack of awareness, poor community engagement, weak parenting, rote learning and negligence. The present study establishes the same. In the present study, young children in 7 - 14 years' group with poor nutrition and poor hygienic conditions were affected more in number (44\%). Due to such poor nutrition and poor sanitation, they remain more susceptible to viral infections and weakened immunity, thereby makes it a bit longer to achieve the normal platelet count. 10

\section{CONCLUSION}

The study tries to explore the link between nutrition and sanitation to acute viral fever with thrombocytopenia. Though, the results depict the same, it requires further research and more sampling needs to be done. Balanced diet, good hygienic habits, minimal stress, regular body exercise like yoga can improve the body immunity to attack viral and bacterial infections. Though, there are no proper drugs for viral infections, few natural sources of remedies that could be tried include consuming papaya leaves, spinach and kiwi fruits etc. There is also a need for establishment of counselling centres and health education by the government regarding sanitation and good hygiene habits. With growing population, urbanisation and globalisation we need to lay more stress on the public health education. In this light, National Health Policy 2017 does make a positive step by emphasising on creating public health education cadres across the country.

The government must ensure more decentralised management of public health by involving Panchayats, Gram Sabha and Civil Society to ensure good sanitation and proper waste management. Awareness generation must be improved through active participation of civil society. The Government's programme of Swach Bharat has made a right beginning and is on its way to make big strides in the future. In addition, the government must ensure its nutrition strategy focussed on 'balanced diets' rather than skewing it in favour of only select food items. For instance, the present Public Distribution System (PDS) does not procure pulses that form an essential protein component. Such drawbacks must be addressed, so that poor get rations that form a balanced diet. The recent programme of National Nutrition Mission and National Nutrition Strategy is expected to bring in such changes and result in positive outcomes. Finally, the above suggestions/ advices regarding good food habits, exercise and games, balanced nutritious diet, avoiding stress and maintaining normal sleep must be disseminated to the public.

\section{REFERENCES}

[1] Chatterjee CC. C Chatterjee's Human physiology revised enlarged. Vol. 1. 11 th coloured edn. CBS Publishers \& Distributors Pvt Ltd., 2016.

[2] Pal GK, Pravati P. Textbook of Practical Physiology. 3rd edn. Hyderabad: Universities Press 2010.

[3] Jain AK. Manual of Practical physiology. India: Arya Publication Reprint 2017.

[4] Hall JE. Guyton and Hall textbook of medical physiology. 13 ${ }^{\text {th }}$ edn. Philadelphia, PA: Elsevier 2016.

[5] Best CH, Taylor NB. The physiological basis of medical practice. $3^{\text {rd }}$ edn. Baltimore: The Williams and Wilkins Company 1943. 
[6] Dacie JV, Lewis SM, Bain BJ, et al. Dacie and Lewis Practical haematology. $10^{\text {th }}$ edn. Churchill Livingstone/Elsevier 2006.

[7] Levy MN, Berne RM, Koeppen BM, et al. Berne \& Levy Principles of physiology. $4^{\text {th }}$ edn. Philadelphia: Elsevier Mosby 2006.

[8] Ganong WF, Barrett KE. Review of medical physiology. New York: McGraw-Hill Medical Publication 2005.
[9] Kasper DL, Fauci AS, Hauser SL, et al. Harrison's principles of internal medicine. 19th edn. New York: McGraw-Hill Education 2015.

[10] Royer DJ, George JN, Terrell DR. Thrombocytopenia as an adverse effect of complementary and alternative medicines, herbal remedies, nutritional supplements, foods and beverages. Eur J Haematol 2010;84(5):4219. 